\title{
$\mathrm{C}|\mathrm{E}| \mathrm{D}|\mathrm{L}| \mathrm{A} \mid \mathrm{S}$
}

Centro de Estudios

Distributivos, Laborales y Sociales

Maestría en Economía

Universidad Nacional de La Plata

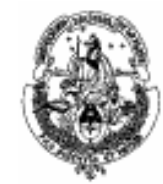

\section{Capital Accumulation, Trade Liberalization and Rising Wage Inequality: The Case of Argentina}

\section{Pablo Acosta y Leonardo Gasparini}

Documento de Trabajo Nro. 5

Enero, 2004 


\title{
Capital Accumulation, Trade Liberalization,
}

\section{and Rising Wage Inequality:}

\section{The Case of Argentina}

\author{
Pablo Acosta* \\ University of Illinois at Urbana-Champaign \\ Leonardo Gasparini \\ CEDLAS - Universidad Nacional de La Plata
}

Revised version: July 24, 2006

\begin{abstract}
Capital accumulation can modify the relative productivity between skilled and unskilled workers, leading to changes in the wage structure. In particular, if capital goods are relatively more complementary to skilled workers, a positive correlation between investment in physical capital and the wage premium would be expected. In this paper, we present evidence for this hypothesis by taking advantage of the variability in wage premia and capital investment across industries in the Argentina's manufacturing sector. We conclude that the wage premium for skilled workers increased more in those industries with higher investment in machinery and equipment. The overall evidence seems to indicate that industry affiliation is an important determinant of earnings differentials by skill group.
\end{abstract}

JEL classification: J31 - F16 - 033

Keywords: wage inequality, capital accumulation, trade liberalization, Argentina

\footnotetext{
* Pablo Acosta (corresponding author): Department of Economics, University of Illinois at Urbana-Champaign. 1206 S. Sixth Street, Champaign, Illinois 61820, USA. E-mail: pacosta@uiuc.edu. Leonardo Gasparini: Centro de Estudios Distributivos, Laborales y Sociales (CEDLAS), Departamento de Economía, Universidad Nacional de La Plata, calle 6 entre 47 y 48, oficina 516, (1900) La Plata, Argentina. E-mail: leonardo@depeco.econo.unlp.edu.ar. This research was supported by the Tinker Field Research Grant, Center for Latin American and Caribbean Studies, University of Illinois at Urbana-Champaign, and CEDLAS, Universidad Nacional de La Plata. We would like to thank Kevin Hallock, Todd Elder, Hadi Esfahani, Werner Baer, two anonymous referees, and seminar participants at University of Illinois at Urbana-Champaign, Universidad Nacional de La Plata, Asociación Argentina de Economía Política (Tucumán, Argentina), Network of Inequality and Poverty (NIP) (Buenos Aires, Argentina), and the Latin American and Caribbean Economic Association (LACEA) Meeting (Puebla, Mexico). The usual disclaimer applies.
} 


\section{Introduction}

Investment in machinery and equipment can affect the wage premium for skilled workers through at least two channels. First, capital goods are usually believed to be skill-complementary (see Krusell et al., 2000, among others). Consequently, higher rates of capital investment should increase the relative productivity of skilled workers. Second, new machinery and equipment may incorporate skill-biased technological innovations. The empirical literature suggests that capital accumulation and technological change are the main reasons behind the observed rising skill premium in many developed countries.

This paper is aimed at providing empirical evidence on the link between capital investment and rising wage inequality in Argentina, the Latin American country that has experienced the largest increase in inequality since the early 1990s (World Bank, 2004) and for which the speed and depth of economic reforms were among the largest in the region (Lora, 1997; Behrman et al., 2001). Between 1992 and 2001, the Gini coefficient for the distribution of household per capita income climbed from 0.450 to 0.522 , while the Gini for the distribution of hourly wages increased from 0.400 to 0.445 (CEDLAS, 2006). During the same period, the Argentinean economy experienced strong capital accumulation and technological change. Foreign Direct Investment grew 11.2\% annually between 1991 and 2000, while Fixed Gross Investment in machinery and equipment increased $6.8 \%$ per year during the same period. These figures are in sharp contrast to the negative values of the previous decade. In the 1990s, encouraged by a novel framework of macroeconomic stability, privatization, deregulation, and trade and financial liberalization, many firms strongly invested in physical capital and adopted new technologies. The intensity of this process was not uniform across economic sectors. In some industries, 
investment merely replaced depreciated capital stock (e.g., leather and footwear), while in others net investment in machinery and equipment was strong (e.g., chemicals and petrochemicals).

This paper assesses the effect of capital accumulation on the observed wage gap between skilled and unskilled workers in the manufacturing sector in Argentina. The existing literature on the determinants of the rising wage premia in that Latin American country is limited to a study by Galiani and Sanguinetti (2003). They conclude that wage differences between skilled and unskilled workers in manufacturing sectors in Greater Buenos Aires increased more in industries with higher import penetration (explaining roughly $10 \%$ of the total wage gap increase). In contrast, other studies on Latin American countries-Attanasio et al. (2004) in the case of Colombia and Pavcnik et al. (2004) for Brazil—find no significant impact of trade liberalization on industry-specific skill premia.

To the best of our knowledge, this is the first paper that provides evidence of the relationship between capital investment and skill premium in Latin America. Related studies include Pavcnik (2003), who presents evidence on the complementary relationship between skill-upgrading and the adoption of new technologies at the plant level in Chile, and Goldberg and Pavcnik (2005), who relate gross capital accumulation levels to industry rents in Colombia. Neither study finds a significant impact of investment (as opposed to trade exposure) on industry-specific skill premia. Other studies in Latin America suggest that technological progress could be behind the increase in wage inequality in the region, although they arrive at this conclusion indirectly (Behrman et al., 2001; Sánchez-Páramo and Schady, 2003).

In this paper, we present evidence for the relationship between capital accumulation and the wage structure by taking advantage of the variability in wage premia and capital investment across industries in Argentina's manufacturing sector. We use repeated cross-sectional data from 
the Permanent Household Survey (EPH) between 1991 and 2001, as well as official data on import penetration, exports, and investment in machinery and equipment in manufacturing sectors (see the Appendix for a detailed description of the data). Our results suggest that in sectors in which capital accumulation has been more intense, the wage gap between skilled and unskilled workers has significantly widened. Although we are unable to identify causal effects, we take the results as preliminary evidence for the major impact of capital accumulation on wage inequality in the manufacturing sector of Argentina.

The remainder of the paper is organized as follows. Section II presents the evolution of wages and employment by educational group in Argentina. Section III is a brief review of some theoretical arguments linking physical capital to the wage structure. Section IV shows the results at the industry level of the links between capital accumulation and industry-specific skill premia, while section V contains a similar analysis, but at the individual level. The paper concludes with some brief comments in section VI.

\section{Wages and employment}

Wage inequality substantially increased in Argentina during the 1990s, compared to previous decades. ${ }^{1}$ Figure 1 shows real hourly wages for workers between 18 and 65 years of age in Greater Buenos Aires (GBA), the main urban area of Argentina (34\% of total population). ${ }^{2}$ The figure shows the evolution of real hourly wages for the median worker and those located at the 90th and 10th percentiles. The wage gap between these two percentiles shrunk during the 1980s, mainly due to decreasing real wages for individuals at the top of the distribution, and widened

\footnotetext{
${ }^{1}$ See Galiani and Sanguinetti (2003), Gasparini (2003), and CEDLAS (2006).
} 
between 1991 and 2001. In that period, while the median hourly wage increased 4\%, real wages increased $31 \%$ for workers at the $90^{\text {th }}$ percentile, and fell $15 \%$ for workers at the $10^{\text {th }}$ percentile.

This paper is aimed at exploring changes in wages by skill group. Figure 2 shows the evolution of the wage premia for skilled workers (defined as those with at least a high school degree) for the period 1985-2001 in Greater Buenos Aires, both across all sectors in the economy and only in the manufacturing sector (20\% average employment share during this period). The skill premium for each year is calculated by regressing the logarithm of hourly wage of the main occupation on a high school graduation indicator, along with other controls such as age, age squared, and gender (population weights considered). The skill premium declined until 1993, from where it started an ascending path, and returns to high school graduation increased by $48 \%$ between 1993 and 2001 in the manufacturing sector (47\% for the whole economy). Changes for the rest of the urban areas also have been significant, although milder; the skill premium rose $15 \%$ in the manufacturing sector and $27 \%$ in the economy.

If each skill group is homogeneous and the labor market adjusts quickly, the wage gap between the skilled and the unskilled should not differ across economic sectors. Instead, with unobservable heterogeneity and high adjustment costs, industry differences in the wage structure could persist for a long period of time (Hamermesh, 1993). ${ }^{3}$ We compute the sector-specific skill premium by means of the following specification:

$$
\ln \left(w_{i j t}\right)=X_{i j t} \beta_{X}+I_{i j t} \beta_{I}+\left(I_{i j t} * S_{i j t}\right) * S P_{j t}+\varepsilon_{i j t}
$$

where $w_{i j t}$ is the hourly wage of individual $i$ working in industry $j$ at time $t, X_{i j t}$ is a vector of workers' characteristics (age, age squared, gender, and regional indicators), $I_{i j t}$ is a set of industry

\footnotetext{
${ }^{2} \mathrm{GBA}$ is one of the few regions for which household survey data prior to 1991 is available.

${ }^{3}$ Heckman and Pages-Serra (2000) present evidence that labor market regulations in Latin America significantly obstruct labor mobility across sectors.
} 
indicators, and $S_{i j t}$ is an indicator for whether worker $i$ in industry $j$ at time $t$ is skilled (has a high school degree). The coefficients $S P_{j t}$ are the sector-specific skill premia, representing the additional wage skilled workers earn in a given industry at time $t$, compared to the base wage received for both skilled and unskilled workers in each industry.

The first column in Table 1 shows the set of relative industry-specific skill premia for the year 1991 in all urban areas with household survey coverage (see Appendix). These are calculated setting the omitted industry-specific skill premium to zero and then expressed as deviations from the employment-weighted average skill premium (Krueger and Summer, 1988). Each value represents the proportional wage difference through an industry-specific skill premium for a skilled worker in a given industry relative to the average skilled worker in the economy with the same observable characteristics. Table 1 confirms the existence of substantial differences in skill premium levels and changes across manufacturing sectors in Argentina.

Changes in wage differentials by educational levels could be attributed to supply-side factors, such as changes in the scarcity of educated workers. The hypothesis of rising wage inequality due to the falling relative supply of skilled workers seems implausible in Argentina. The proportion of 18- to 65 year-old individuals with a high school degree in Greater Buenos Aires jumped from $26 \%$ in 1985 to $46 \%$ in 2001. In all of urban Argentina, the change was similar-from $37 \%$ in 1991 to $46 \%$ in $2001 .{ }^{4}$ Table 2 shows that the national employment share of skilled workers increased in every industry during the 1990s. In 1991, $28 \%$ of manufacturing workers were skilled, and that share climbed to $43 \%$ in 2001.

In summary, during the 1990s, Argentina witnessed a significant growth in the labor supply and employment of skilled individuals, along with a substantial increase in the wage premia to

\footnotetext{
${ }^{4}$ According to Census data, migrations were not significant in the period under analysis.
} 
these workers, which suggests strong changes in the relative labor demands. In sections IV and V, we exploit the variability in relative wages across industries in order to relate changes in wage premia to demand-shift explanations. But first, in the next section, we briefly present a theoretical argument linking the wage premia to capital investment.

\section{Capital investment, technology, and wages}

One of the arguments to explain rising wage inequality relies on physical capital investments. If machines and equipment are skilled-complementary, an increase in capital utilization levels should lead to an increase in the relative productivity of skilled workers and, consequently, a rise in the wage premia. Following Krusell et al. (2000), we propose an illustrative model with implications for the changes in industry-specific skill premia. Assume that firms within a specific sector $n$ produce $q$ units with a constant-elasticity-of-substitution (CES) technology, and three inputs: capital $(k)$, skilled workers $\left(l_{s}\right)$, and unskilled workers $\left(l_{u}\right)$, expressed in terms of efficiency units. To simplify the analysis, assume also that the elasticity of substitution between skilled and unskilled workers is equal to the elasticity of substitution between unskilled workers and capital. ${ }^{5}$

$$
q_{n t}=\left[\theta_{n}\left(\psi_{u n t} h_{u n t}\right)^{\sigma_{n}}+\left(1-\theta_{n}\right)\left(\lambda_{n} k_{n t}^{\rho_{n}}+\left(1-\lambda_{n}\right)\left(\psi_{s n t} h_{s n t}\right)^{\rho_{n}}\right)^{\frac{\sigma_{n}}{\rho_{n}}}\right]^{\frac{1}{\sigma_{n}}}
$$

Each labor input is the product of worked hours $(h)$ and an efficiency index. For skilled workers, $l_{s}=\psi_{s} h_{s}$, while for the unskilled $l_{u}=\psi_{u} h_{u} . \theta$ and $\lambda$ represent the factor shares, while $\sigma$ and $\rho$ (both less than 1) determine the elasticity of substitution between inputs. Specifically, the

\footnotetext{
${ }^{5}$ See Hammeresh (1993) and Goldin and Katz (1998) for a discussion of this assumption.
} 
elasticity of substitution between capital and unskilled labor is $\delta=1 /(1-\sigma)$, which is also equal (by assumption) to the elasticity of substitution between skilled and unskilled workers. The elasticity of substitution between capital and skilled labor is $\gamma=1 /(1-\rho)$. A higher complementarity between capital and skilled labor, compared to the complementarity between capital and unskilled labor, requires that $\sigma$ be greater than $\rho$.

From equation (2) and assuming that wages are equal to the marginal productivity of labor, the skill premium $\pi_{n t}$ (the wage ratio between skilled and unskilled workers) for sector $n$ at time $t$ can be written as:

$$
\pi_{n t}=\frac{\left(1-\theta_{n}\right)\left(1-\lambda_{n}\right)}{\theta_{n}}\left[\lambda_{n}\left(\frac{k_{u n t}}{l_{\text {snt }}}\right)^{\rho_{n}}+\left(1-\lambda_{n}\right)\right]^{\frac{\left(\sigma_{n}-\rho_{n}\right)}{\rho_{n}}}\left(\frac{h_{u n t}}{h_{\text {snt }}}\right)^{1-\sigma_{n}}\left(\frac{\psi_{\text {snt }}}{\psi_{u n t}}\right)^{\sigma_{n}}
$$

Taking logs, differentiating (3) with respect to time, and denoting the rate of growth of the variable $x$ as $g_{x}$, yields:

$$
g_{\pi t} \approx(\sigma-1)\left(g_{h s t}-g_{h u t}\right)+\sigma\left(g_{\psi s t}-g_{\psi u t}\right)+(\sigma-\rho) \lambda\left(\frac{k_{t}}{l_{s t}}\right)^{\rho}\left(g_{k t}-g_{h s t}-g_{h u t}\right)
$$

According to equation (4), the change in the skill premium can be divided into three components. The first represents the relative change in factor endowments $\left(g_{h s t}-g_{h u t}\right)$ : the higher the relative rate of growth of skilled labor, the smaller the wage premia (as $\sigma<1$ ). The second component captures the growth in the relative efficiency among educational groups. If $\sigma>0$, an increase in the relative efficiency of skilled workers generates an increase in the skill premium. Finally, the third term measures what Krusell et al. (2000) call the "complementary effect." As previously mentioned, if $\sigma$ is greater than $\rho$, then capital is more skill-complementary. In this case, higher investment in machinery and equipment would increase the skill premium. 
Even when capital is not skill-complementary, higher capital accumulation levels could increase the skill premium $\pi$. If new capital goods incorporate imbedded technological change, an increase in investment in new machinery and equipment can accelerate the adoption of new technologies. Incorporation of capital associated with new technologies (e.g., computers and information technology) can increase skilled workers' relative efficiency, thus generating a rise in the skill wage gap.

In equation (4), capital incorporation associated with new technologies would increase skilled workers' relative efficiency through the second term of the equation $\left(g_{\psi s t}-g_{\psi u t}\right)$. Many authors share the view that skill-biased technological change is the main factor behind the observed changes in the wage structure in developed countries in the last few decades. ${ }^{6}$ If skillbiased technologies developed in the North are transmitted to the South, we would expect industries that invest heavily in foreign capital goods to have a higher increase in skill premium through the increase in the relative efficiency of skilled workers. Some recent papers suggest that skill-biased technological change can be transferred through trade, in particular through imports with high R\&D content (Attanasio et al., 2004; Pavcnik et al., 2004; Sánchez-Páramo and Schady, 2004).

Of course, there are other factors that can affect the wage structure that are not being considered in equation (4). In particular, two have been extensively studied in the economic literature: labor institutions and international trade. The declining power of unions and the reduction in the minimum wage may have negatively affected unskilled workers' wages. Unions tend to reduce the wage gap through collective bargaining, compressing the distribution of

\footnotetext{
${ }^{6}$ See Bound and Johnson (1992), Katz and Murphy (1992), Gottschalk and Smeeding (1997), Feenstra and Hanson (1999), Autor et al. (1998), Autor et al. (2001), Acemoglu (2002), and Autor et al. (2006) for evidence in favor of SBTC as the main force behind the rise in wage inequality in the US. Card and DiNardo (2002) challenge this hypothesis.
} 
earnings. If these institutions lose power, the force that prevents a reduction in the relative wages of the low-skilled workers weakens (see DiNardo et al., 1996). Economic theory also predicts changes in the wage structure caused by changes in international trade. According to the StolperSamuelson theorem, if tariff reductions are proportionally larger in sectors employing relatively more unskilled workers, these workers will experience a decline in their relative wages. ${ }^{7}$

In principle, the three explanations - capital accumulation, trade liberalization, and declining union power-could apply to the Argentinean case. First, there is some evidence of the decline of union membership in Argentina. Sánchez-Páramo and Schady (2004) report a fall in union density from $27.4 \%$ in the 1980 s to $24.6 \%$ in $1995 / 99$.

Second, Argentina witnessed strong physical capital incorporation during the 1990s (Acosta and Loza, 2005). Foreign Direct Investment increased at an annual growth rate of $11.2 \%$ between 1991 and 2000, and Fixed Gross Investment in machinery and, during the same period, equipment grew at $6.8 \%$ per year. The relative price of capital goods declined $10 \%$ between 1993 and 2000, with respect to other manufacturing goods, presumably due to the real exchange rate appreciation and tariff reductions. The largest import tariff reductions were implemented in durable goods, machinery, and transport equipment, from an average of $60 \%$ in 1988 , to $23 \%$ in 1991, and 12\% in 1993 (Berlinski, 2003). These changes, together with a more favorable business environment for investment, generated a significant increase in the capital stock, particularly of imported machinery and equipment. FIEL (2002) estimates that the physical capital stock (excluding the public sector) grew by $20 \%$ between 1992 and 1999.

Tariff reductions were not limited to capital goods. Trade liberalization started gradually by the end of the 1980s and was extended to almost all sectors in the economy during the 1990s.

\footnotetext{
${ }^{7}$ See Wood (1994), Leamer (1995), Gottschalk and Smeeding (1997), and Attanasio et al. (2004).
} 
Berlinski (2003) reports that, in most manufacturing sectors, tariffs declined in the 1990s from a weighted average of $48 \%$ in 1988 to $16 \%$ in 1997 . Changes in trade policy also included the end of sector-specific subsides with protectionist goals, the elimination of most non-tariff barriers, and a commercial agreement with neighbor countries (Mercosur).

\section{Industry-Specific Skill Premium, Capital, and Trade Exposure}

Neither physical capital accumulation nor changes in international trade (and, presumably, in unionization rates) have occurred with the same intensity across industries. In this section, we exploit the variability in capital investment and import penetration across industries in order to associate these phenomena to changes in the wage structure. It is important to point out from the start that it is difficult to explain differences in capital accumulation paths adopted by manufacturing industries in Argentina with the data at hand. If, as we presume, differences in the intensity of capital investment in the 1990s were mainly driven by factors not correlated with skill premium changes (e.g., differences in the distance to the technological frontier after a decade-

the 1980s-without investments or differential capital tax treatments), then our results can be interpreted as preliminary evidence of the causal effect of capital accumulation over the wage structure. If, instead, other underlying factors were driving both capital investment and wages, the results of this paper are just empirical evidence of the strength of the correlations between these variables.

There is little information on capital and technology by sector in Argentina or on the R\&D content of imports. We take advantage of the fact that the Argentina's Secretary of Industry released estimates on machinery and equipment gross investments in manufacturing sectors for 
the period 1990-2001, based on firm surveys (see Appendix for data sources). We normalize this variable using sectoral gross value-added (GVA) to get a proper capital accumulation measure. This indicator has some limitations. It is restricted to the manufacturing sector and captures gross investment, instead of capital stock or net investment. Additionally, the indicator does not identify whether the new machines incorporate new technology, so we cannot distinguish between technological change and pure capital accumulation effects (second and third terms in equation 4).

The last three columns in Table 1 show investment in machinery and equipment, import penetration, and exports for the period 1991-2001 (as a share of accumulated gross value added). The classification into 14 manufacturing sectors (as opposed to the 22 sectors' standard two-digit ISIC) is due to two reasons: (a) in Argentina, official statistics on capital accumulation are broken down in 17 sectors; and (b) three of these 17 sectors have small employment shares (less than $1 \%$ ) in the manufacturing sector and are therefore merged into other similar product categories.

The simple linear correlation of changes in capital accumulation and in the skill wage premia between 1991 and 2001 is 0.193 . When we pool all industries and years in the sample (14 industries x 11 years), changes in skill premium are weakly correlated with changes in investment in machinery and equipment (0.107), negligibly correlated with changes in import penetration (0.036), and negatively correlated with export ratios $(-0.089)$.

To evaluate the determinants of industry-specific skill premia, we start with a reduced-form specification at the industry level (see Attanasio et al., 2004, and Pavcnik et al., 2004):

$$
S P_{j t}=K_{j t} \beta_{K}+M_{j t} \beta_{M}+X_{j t} \beta_{X}+T_{t} \beta_{T}+I_{j} \beta_{I}+\mu_{j t}
$$

Industry skill premia $\left(S P_{j t}\right)$ are pooled over time $t$ and regressed on a vector of investment in machinery and equipment $\left(K_{j t}\right)$ and import penetration $\left(M_{j t}\right)$, both normalized over gross value 
added and expressed in logarithms. A vector of additional control variables $\left(X_{j t}\right)$ captures other observable time-varying industry factors, such as exports (as a share of GVA), and the skilled/unskilled and male/female employment ratios. The vectors $T_{t}$ and $I_{j}$ are the sets of year and industry indicators. To account for heteroscedasticity and serial correlation in the error term $\left(\mu_{j t}\right)$, robust Huber-White standard errors are computed, clustered at the industry level. We also estimate equation (5) in first differences. Following Krueger and Summers (1988), each sectoryear observation is weighted by the inverse of the standard error of the sectorial skill premium (using the standard error of the intercept for the omitted sector). ${ }^{8}$ The coefficients on capital accumulation and import penetration should not be capturing industry differences in worker composition correlated with investment decisions or trade protection policies, as in order to construct industry-specific skill premia we had to first control for worker characteristics. Similarly, as suggested in Pavcnik et al. (2004), because returns to worker characteristics are allowed to differ year by year in the computation of skill premia, all economy-wide changes in returns to worker characteristics associated with changes in labor supply over time are already taken into account.

Table 3 presents the results for the models of skill premium in levels (columns 1 to 6) and first differences (columns 7 and 8). The numbers in the first column suggest that capital investment levels are positively and significantly correlated with skill premium at the industry level. Of course, other controls need to be taken into account. The second column, for instance,

\footnotetext{
${ }^{8}$ Assigning equal weights to every sector each year does not alter significantly the results presented in Table 3. Attanasio et al. (2004), and Pavcnik et al. (2004) follow Haisken-DeNew and Schmidt (1997) two-step restricted least squares procedure for the calculation of the exact standard errors of the sectorial skill premia after using Krueger and Summers (1988) normalization. However, as suggested in Haisken-DeNew and Schmidt (1997), the gains from using the exact formulation are minimum when industry differences are calculated using large samples (i.e., household survey data).
} 
introduces import penetration ratios as a means to determine whether they also have an influence on the wage structure. While capital accumulation remains significant, there is no impact from the import penetration variable.

Other time-varying industry characteristics may affect the wage structure. Although presumably posing endogeneity concerns, columns 3 to 6 add export ratios and skilled/unskilled and male/female employment ratios as control variables. For instance, workers with different educational levels (or gender) might differ in their ability to bargain over wages. Indeed, Revenga (1997) finds that, in Mexico, the higher the proportion of unskilled workers in a given sector, the lower their ability to capture industry rents. Table 3 shows that all control variables are nonsignificant. Adding controls does not substantially change the main result of the effect of capital investment on the skill wage premia.

As discussed above, differences in capital investment across industries may not be exogenous. Some unobserved factors could potentially cause some industries to simultaneously increase investments in physical capital and bid up the wage of skilled workers. A higher skill premium could have been caused by an unobserved demand shifter (e.g., technological change), with industries increasing both physical capital and skilled labor at the same time in order to increase output. If this is the case, the evidence would still suggest that skilled labor and physical capital are complements in production in these industries, but this does not mean that capital accumulation was the cause of rising skill premia. This endogeneity concern also can apply to the case of import penetration and exports, as trade flows depend on factor costs.

In the absence of reliable instruments, it is difficult to overcome this causality problem. To somehow alleviate it, capital accumulation, import penetration, and export ratios are lagged one period in column 5. Of course, the endogeneity problem would still remain under adjustment 
costs to capital, as firms would prefer to smoothly increase capital stock over time. Using lagged right-hand-side variables addresses an additional concern: the effect of capital investment on relative labor productivity may not be contemporaneous. The results in column 5 are similar to those in column 3. The coefficient on capital accumulation is a little lower (0.027) than the one for the contemporaneous case (0.034).

Other time-invariant characteristics at the industry level could be correlated with capital investment and the wage structure. To take that into account in column 6 , we add sector fixed effects. The coefficient of capital accumulation is reduced to half (0.015), but it is still significant at the $5 \%$ level. Even by controlling for specific characteristics at the industry level, the main result of interest remains significant.

Columns 7 and 8 present the regression specification in first differences. Changes in investment in machinery and equipment have a positive and significant effect on changes in sector skill premia. In contrast, changes in import penetration and export ratios are not significantly correlated with changes in wage differentials by educational level. The addition of other controls does not affect this result.

In summary, at the industry level, capital accumulation seems to be positively and significantly correlated with relative wages for skilled workers. In contrast, trade exposure does not appear to be related to changes in the skill premium. The next section assesses whether this result remains valid when looking at individual-level data in a traditional wage equation.

\section{Evidence at the Individual Level}


In this section, we extend the methodology to take advantage of household survey data at the individual level. The equation to be estimated is an individual-level Mincer-type semi-log wage regression. The dependent variable is the logarithm of the real hourly wage of the main occupation, which is regressed on variables that interact the individual educational level with sector specific capital accumulation and import penetration variables. Specifically:

$$
\begin{aligned}
\ln w_{i} & =T_{i} \sum_{g=2}^{3} E_{i}^{g} \beta_{g t}^{E}+\sum_{g=1}^{3} E_{i}^{g} m_{i} \beta_{g}^{m}+\sum_{g=1}^{3} E_{i}^{g} k_{i} \beta_{g}^{k}+ \\
& +T_{i} Z_{i} \beta_{t}^{Z}+T_{i} \beta_{t}^{T}+R_{i} \beta_{r}^{R}+C_{i} \beta_{c}^{C}+\varepsilon_{i}
\end{aligned}
$$

where $w_{i}$ is individual $i$ 's hourly wage in his or her main activity. For simplicity, in the notation, we ignore the rest of the subscripts. Each individual $i$ has associated an industry $j$ where he or she works, a city $c$ where he or she lives, and a time period $t$ in which he or she was interviewed by the household survey. We consider three educational groups: without a high-school degree ( $g=$ 1), high-school graduates ( $g=2$ ), and college graduates $(g=3) . E^{g}$ is the indicator variable for educational level $g$. The contributions of this model, compared to a typical wage equation, are included in the second and third terms of equation (6). The variable $m_{i}\left(k_{i}\right)$ denotes the logarithm of import penetration (capital accumulation) over gross value added for the sector where individual $i$ worked in year $t$. As these variables interact with educational dummies, the model allows import penetration and capital accumulation to have differential effects by skill. The regression also includes control variables $\left(Z_{i}\right)$ at the individual level (gender, age). The estimated coefficients for the educational dummies and for control variables $\mathrm{Z}$ are allowed to vary by year ( $T_{i}$ is the set of year dummies). Finally, equation (6) includes time ( $\left.T\right)$, industry $(R)$, and city $(C)$ fixed effects.

The interpretation of the coefficients $\beta^{n}$ and $\beta^{k}$ is as follows: consider two individuals labeled as $s$ and $u$, only differing in their educational level, whereby $s$ is a college graduate, while 
$u$ does not have a high-school degree. From equation (6) and denoting with a "hat" the estimated value of the coefficients,

$$
\ln \hat{w}_{s}-\ln \hat{w}_{u}=\left(\hat{\beta}_{3 t}^{E}-\hat{\beta}_{2 t}^{E}\right)+\left(\hat{\beta}_{3}^{m}-\hat{\beta}_{2}^{m}\right) m_{s}+\left(\hat{\beta}_{3}^{k}-\hat{\beta}_{2}^{k}\right) k_{s}
$$

where $m_{s}=m_{u}$ and $k_{s}=k_{u}$, since both individuals work in the same sector. The wage premia is the sum of three terms: the traditional one and those capturing the effects of import penetration and capital accumulation. Based on the discussion in section III, all three differences are expected to be positive.

Equation (6) is estimated for individuals aged 18 to 65 , with positive wage earnings and working in the manufacturing sector between 1991 and 2001. This part of the analysis resembles Galiani and Sanguinetti's (2003) study. We extend their paper in two directions: (i) expanding the geographical analysis to most of the urban areas in Argentina (and therefore substantially increasing the sample size) and, more importantly, (ii) evaluating an additional source of differences in the observed wage gaps by sector-capital accumulation.

Table 4 shows the results of estimating equation (6) using weighted least squares. For simplicity, we exclude the estimated coefficients for the control variables. The first column starts by looking at capital accumulation coefficients. Investment in machinery and equipment is positively correlated with the wage gaps by skill level. An additional $1 \%$ investment in machinery and equipment (as a share of gross value added) is associated with a $3.3 \%$ increase in the wage gap between college graduates and high-school dropouts. Column 2 adds import penetration by sector; no significant association between this variable and the wage gap is found. ${ }^{9}$ The results do

\footnotetext{
${ }^{9}$ Galiani and Sanguinetti (2003) find for the Greater Buenos Aires area in the period 1992-1999 that an increase in import penetration widens the wage gap between skilled workers and the rest. We are able to get significant impacts of import penetration ratios using their specification and data coverage, although they are of minor order compared to capital accumulation effects. As in our case, in their study, import penetration ratios do not significantly alter the wage gap between medium- and low-skilled groups.
} 
not vary in column 3, where we control for export ratios. Similarly, results do not significantly change when capital accumulation, import, and export ratios are introduced lagged one and two periods, respectively (see columns 4 and 5).

As discussed above, we interpret these results as preliminary evidence of the importance that investment in machinery and equipment had in shaping the wage structure in Argentina during the 1990s. Of course other explanations are possible. One may argue, for instance, that highinvestment sectors are presumably more likely to be the ones having higher profits. In the presence of rent sharing in wage determination, the estimates reported may be capturing a rent sharing advantage of skilled workers in those sectors (Revenga, 1997). It is difficult to disentangle this effect in the absence of data on wage compensation practices, although it is widely cited in the literature of compensations that rent sharing practices are less common in developing countries.

\section{Final comments}

Capital accumulation can increase the wage gap between skilled and unskilled workers if capital is skill-complementary, and if it has incorporated skilled-biased technological change. The evidence for developed countries indicates that this phenomenon is important in accounting for the observed increase in the wage premia during the last decades. Argentina seems to have adopted these results as a consequence of the accelerated capital incorporation process that occurred during the 1990s.

Combining cross-sectional microdata from a household survey with aggregate data on capital accumulation and import penetration for different manufacturing industries, the paper suggests 
that higher investment in machinery and equipment in a particular industry is associated with an increase in the wage premia for skilled workers in that industry. The investment effect seems to have been substantially larger than the trade exposure effect.

Of course, other unobserved industry and time-varying factors correlated with both capital accumulation and returns to education could be playing a role, posing identification problems. Even though the main results hold after considering lagged values of the variables of interest, causality interpretations should be made with caution in absence of good instrumental variables. 


\section{References}

Acemoglu, D. 2002. "Technical change, inequality, and the labor market." Journal of Economic Literature 40, 7-72.

Acosta, P., A. Loza. 2005. "Short and long run determinants of private investment in Argentina." Journal of Applied Economics 8, 389-406.

Attanasio, O., P. Goldberg, and N. Pavcnik. 2004. "Trade reforms and wage inequality in Colombia." Journal of Development Economics 74, 331-366.

Autor, D., L. Katz, and M. Kearney. 2006. “The polarization of the U.S. labor market.” NBER Working Paper 11986.

Autor, D., L. Katz, and A. Krueger. 1998. "Computing inequality: have computers changed the labor market?" Quarterly Journal of Economics 113, 1169-1213.

Autor, D., F. Levy, and R. Murnane. 2001. "Upstairs, downstairs: computers and skills on two floors of a large bank." Industrial and Labor Relations Review 55, 432-447.

Berhman, J., N. Birsdall, and M. Szekely. 2001. "Economic Policy and Wage Differentials in Latin America." University of Pennsylvania, PIER Working Paper 01-048.

Berlinski, J. 2003. "International Trade and Commercial Policy." In A New Economic History of Argentina, Della Paolera, G., Taylor, A. (Eds.), Cambridge University Press.

Card, D., and J. DiNardo. 2002. "Skill biased technological change and rising wage inequality: some problems and puzzles.” Journal of Labor Economics 20, 733-783.

CEDLAS. 2006. Socioeconomic database for Latin America and the Caribbean. $\underline{\text { www.depeco.econo.unlp.edu.ar/cedlas }}$

DiNardo, J., N. Fortin, and T. Lemieux. 1996. "Labor Market Institutions, and the distribution of wages, 1973-1992: A Semiparametric Approach.” Econometrica, 64, 1001-1044.

Feenstra, R., and G. Hanson. 1999. "The impact of outsourcing and high-technology capital on wages: estimates for the United States, 1979-1990." Quarterly Journal of Economics 114, 907-940.

FIEL. 2002. Productividad, competitividad y empresas. Los engranajes del crecimiento. Buenos Aires, Argentina.

Galiani, S., and P. Sanguinetti, P. 2003. "The impact of trade liberalization on wage inequality: evidence from Argentina.” Journal of Development Economics, 72, 497-513. 
Gasparini, L. 2003. “Argentina's distributional failure.” Unpublished manuscript, Inter-American Development Bank.

Goldberg, P., and N. Pavcnik. 2005. "Trade, wages, and the Political Economy of Trade Protection: Evidence from the Colombian Trade Reforms." Journal of International Economics 66, 75-105.

Goldin, C., and L. Katz. 1998. "The origins of technology-skill complementarity." Quarterly Journal of Economics 113, 693-732.

Gottschalk, P., and T. Smeeding. 1997. "Cross-national comparisons of earnings and income inequality." Journal of Economic Literature 35, 633-687.

Haisken-DeNew, J., and C. Schmidt. 1997. "Interindustry and interregion differentials: Mechanics and interpretation.” Review of Economics and Statistics 79, 516-521.

Hamermesh, D. 1993. Labor Demand. Princeton University Press, N.J.

Heckman, J., and C. Pages-Serra. 2000. "The cost of job security regulation: Evidence from Latin American Labor Markets." Economia, Journal of the Latin American and Caribbean Economic Association 1, 109-154.

Katz, L., and K. Murphy. 1992. "Changes in relative wages in the United States: Supply and demand factors." Quarterly Journal of Economics 107, 35-78.

Krueger, A., and L. Summers. 1988. "Efficiency wages and the inter-industry wage structure." Econometrica 56, 259-293.

Krusell, P., L. Ohanian, J. Ríos-Rull, and G. Violante. 2000. "Capital-skill complementarity and inequality: a macroeconomic analysis.” Econometrica 68, 1029-1053.

Leamer, E. 1995. “Trade, wages and revolving-door ideas.” NBER Working Paper 4716.

Lora, E. 1997. "Una década de reformas estructurales en América Latina: que ha sido reformado y cómo medirlo." Papel de trabajo No.348 del IDB-OCE. Washington, DC: Inter-American Development Bank.

Pavcnik, N. 2003. "What explains skill upgrading in less developed countries?" Journal of Development Economics 71, 311-328.

Pavcnik, N., A. Blom, P. Goldberg, and N. Schady. 2004. "Trade liberalization and industry wage structure: Evidence from Brazil.” World Bank Economic Review 18, 319-344.

Revenga, A. 1997. "Employment and Wage Effects of Trade Liberalization: The Case of Mexican Manufacturing." Journal of Labor Economics 15, S20-43. 
C. Sanchez-Paramo, and N. Schady. 2003. "Off and Running? Technology, trade, and the rising demand for skilled workers in Latin America." World Bank, Policy Research Working Paper 3015.

Wood, A. 1994. North-South trade, employment and inequality: changing fortunes in a skill driven world. Oxford University Press.

World Bank. 2004. Inequality in Latin America and the Caribbean: Breaking with History?, Washington D.C: The World Bank. 


\title{
Appendix: Data Sources
}

\author{
Labor Force Data
}

Labor market data comes from Encuesta Permanente de Hogares (EPH), the nationally representative household survey of Argentina. For the period 1991-2001 repeated cross sectional data is available, covering 28 urban areas: Buenos Aires, Greater Buenos Aires, Bahia Blanca, Catamarca, Comodoro Rivadavia, Cordoba, Corrientes, Formosa, Jujuy, La Plata, La Rioja, Mar del Plata, Mendoza, Neuquen, Parana, Posadas, Resistencia, Rio Cuarto, Rio Gallegos, Rosario, Salta, San Juan, San Luis, Santa Fe, Santa Rosa, Santiago del Estero, Tierra del Fuego, and Tucuman. These areas account for nearly two-thirds of the total country's population.

The analysis is restricted to the manufacturing sector, and to 18-65 years old individuals (males and females) with positive earnings. The wage measure is the hourly wage of the main occupation, deflated by the monthly national consumer price index (expressed in 1999 pesos). The main education indicator is completed years of schooling: workers are classified into (i) those with no high-school degree, (ii) with at most a high-school degree, and (iii) with a university degree. Primary education in Argentina consists of seven years of schooling, while secondary education comprises five years of schooling.

\section{Capital Accumulation Data}

Data on machinery and equipment gross investment by manufacturing sector (at current prices) comes from the local Secretary of Industry (Base de Inversiones, Centro de Estudios para la Produccion, Secretaria de Industria, Comercio y PyME, Ministerio de Economia y Producción, www.cep.gov.ar). Estimates of capital accumulation by sector, based on firm surveys, are available for the period 1990-2001.

Unfortunately, the Secretary of Industry does not classify sectors using the 22 sector's standard two-digit ISIC. 17 ISIC sectors can be matched from the Secretary of Industry's classification, although three of them are merged into other similar product categories, as they have small 
employment shares. The 14 sectors considered in the analysis are: Food, Beverages and Tobacco; Textiles and Clothing; Leather and Footwear; Wood and Furniture; Paper; Publishing and Printing; Chemicals and Petrochemicals; Plastics and Rubber Products; Non-metallic Mineral Products; Basic Metallic Products; Fabricated Metallic Products; Machinery and Equipment; Electrical and Electronic Equipment; and Transportation Vehicles.

\section{Trade Exposure Data}

Data on imports and exports by manufacturing sector (at current prices) comes from the Institute for the Integration of Latin America and the Caribbean (INTAL), at the Inter-American Development Bank (IADB). The two-digit ISIC classification was matched into the 14 sectors used for the capital accumulation measures.

\section{Gross Value Added Data}

Gross Value Added (at current prices) by manufacturing sector (at two-digit ISIC classification) is available at the local statistical agency (INDEC, Instituto Nacional de Estadisticas y Censos, www.indec.mecon.gov.ar). The two-digit ISIC classification was matched into the 14 sectors used for the capital accumulation measures. The sectorial capital accumulation and import penetration measures are normalized using Gross Value Added in order to account for the size of each manufacturing sector. 
Figure 1: Hourly Wages

Selected Percentiles, All Sectors

Greater Buenos Aires, 1985-2001

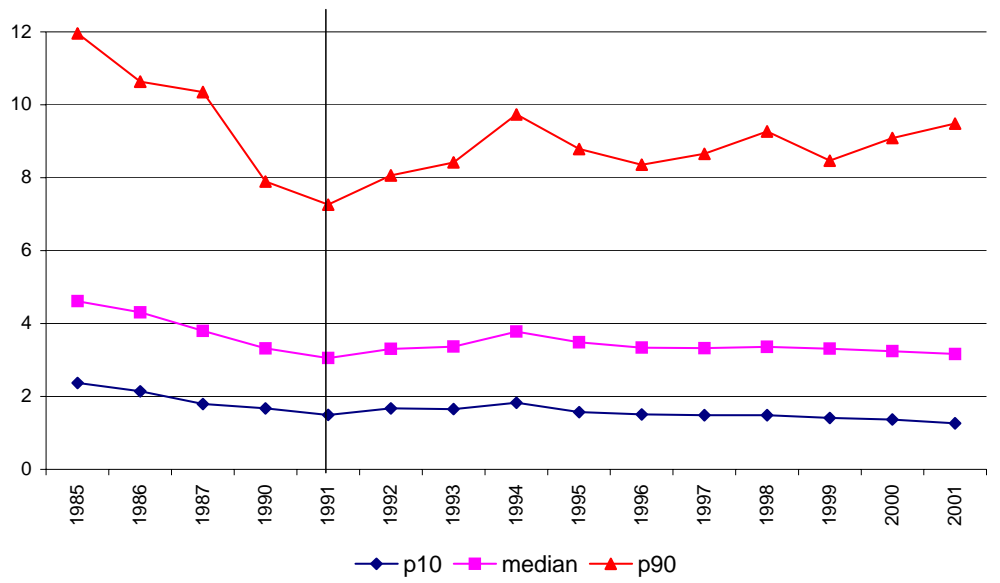

Source: Own calculations based on the Permanent Household Survey (EPH), October round. Note 1: Real wages in 1999 pesos (deflated by CPI).

Note 2: The vertical line at year 1991 indicates the beginning of most of the economic reforms. Note 3: Years 1988 and 1989 (hyperinflation) were deleted from the figure. 
Figure 2: Returns to High-School Graduation

Greater Buenos Aires, 1985-2001

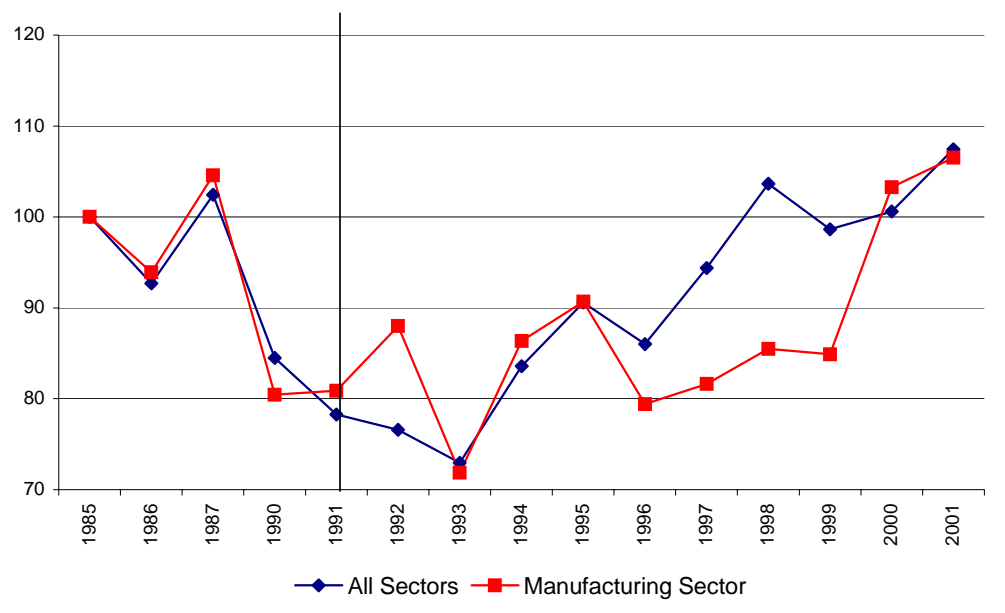

Source: Own calculations based on the Permanent Household Survey (EPH), October round. Note 1: The skill premium for each year is calculated by regressing the logarithm of hourly wage of the main occupation on a high school graduation indicator, along with other controls such as age, age squared, and gender (population weights considered).

Note 2: The vertical line at year 1991 indicates the beginning of most of the economic reforms. Note 3: Years 1988 and 1989 (hyperinflation) were deleted from the figure. 
Table 1

Relative Skill Premium, Investment in Machinery and Equipment, Import Penetration, and Exports by Manufacturing Sector

Argentina, 1991-2001

\begin{tabular}{|c|c|c|c|c|c|}
\hline Sector & $\begin{array}{c}\text { Relative } \\
\text { Skill Premium } \\
\text { Level, } 1991 \\
\text { (i) } \\
\end{array}$ & $\begin{array}{c}\text { Relative } \\
\text { Skill Premium } \\
\text { Change 1991-2001 } \\
\text { (ii) } \\
\end{array}$ & $\begin{array}{c}\text { Investment M\&E / GVA } \\
\text { Accumulated } \\
\text { 1991-2001 } \\
\text { (iii) } \\
\end{array}$ & $\begin{array}{l}\text { Imports / GVA } \\
\text { Accumulated } \\
\text { 1991-2001 } \\
\text { (iv) } \\
\end{array}$ & $\begin{array}{c}\text { Exports / GVA } \\
\text { Accumulated } \\
\text { 1991-2001 } \\
\text { (v) } \\
\end{array}$ \\
\hline Food, beverages and tobacco & 0.16 & -0.12 & 2.7 & 2.8 & 22.1 \\
\hline Textiles and clothing & 0.03 & -0.24 & 0.9 & 13.7 & 6.8 \\
\hline Leather and footwear & -0.30 & 0.11 & 0.8 & 10.4 & 42.3 \\
\hline Wood and furniture & -0.26 & -0.01 & 7.3 & 38.6 & 21.0 \\
\hline Paper & 0.43 & -0.28 & 5.0 & 22.5 & 6.8 \\
\hline Publishing and printing & -0.17 & 0.25 & 0.9 & 8.5 & 3.5 \\
\hline Chemicals and petrochemicals & 0.16 & 0.12 & 6.6 & 23.9 & 13.5 \\
\hline Plastics and rubber products & -0.07 & 0.12 & 2.4 & 24.3 & 6.9 \\
\hline Non-metalilc mineral products & 0.04 & 0.71 & 8.3 & 10.0 & 3.9 \\
\hline Basic metallic products & -0.05 & 0.46 & 3.1 & 18.9 & 21.7 \\
\hline Fabricated metallic products & -0.07 & 0.04 & 0.7 & 19.2 & 4.4 \\
\hline Machinery and equipment & 0.16 & -0.29 & 1.4 & 118.7 & 15.9 \\
\hline Electrical and electronic equipment & -0.08 & 0.08 & 1.2 & 99.8 & 8.0 \\
\hline Transportation Vehicles & -0.08 & -0.07 & 11.0 & 49.7 & 24.8 \\
\hline Correlation with changes in skill pre & & 1.00 & 0.19 & -0.34 & -0.10 \\
\hline
\end{tabular}

Source: Own calculations based on the Permanent Household Survey (EPH), October round; CEP, Secretaría de Industria, Comercio y PyME (investment); INTAL, Inter-American Development Bank (imports, exports).

Note 1: Relative industry-specific skill premia are expressed as deviations from the employment-weighted average skill premium for the manufacturing sector (Krueger and Summer, 1988).

Note 2: GVA=gross value-added 


\section{Table 2}

\section{Skilled Employment by Manufacturing Sector}

(Percentage of Employees with High School Degree by Sector)

Argentina 1991, 1996, 2001

\begin{tabular}{llll}
\hline Sector & 1991 & 1996 & 2001 \\
\hline & & & \\
Food, beverages and tobacco & 27.0 & 29.1 & 38.7 \\
Textiles and clothing & 24.7 & 30.4 & 36.4 \\
Leather and footwear & 13.6 & 20.3 & 18.6 \\
Wood and furniture & 19.1 & 24.2 & 32.3 \\
Paper & 38.8 & 49.8 & 44.9 \\
Publishing and printing & 33.0 & 55.3 & 57.0 \\
Chemicals and petrochemicals & 48.2 & 49.4 & 63.6 \\
Plastics and rubber products & 27.0 & 30.0 & 54.0 \\
Non-metallic mineral products & 27.5 & 19.1 & 29.5 \\
Basic metallic products & 22.9 & 33.1 & 36.5 \\
Fabricated metallic products & 18.2 & 27.3 & 39.6 \\
Machinery and equipment & 40.3 & 50.1 & 47.9 \\
Electrical and electronic equipment & 45.5 & 48.4 & 58.0 \\
Transportation Vehicles & 33.6 & 41.1 & 46.8 \\
& & & \\
Manufacturing Sector & 28.3 & 34.4 & 42.8 \\
All Sectors & & & \\
\hline
\end{tabular}

Source: Own calculations based on the Permanent Household Survey $(\mathrm{EPH})$, October round. (population weights considered). 


\section{Table 3}

\section{Models of Industry-Specific Skill Premia for High-School Graduates}

Estimation at the industry level

Manufacturing Sector, Argentina, 1991-2001

\begin{tabular}{|c|c|c|c|c|c|c|c|c|}
\hline Model & $(1)$ & $(2)$ & $(3)$ & $(4)$ & $(5)$ & $(6)$ & $(7)$ & $(8)$ \\
\hline $\log ($ Investment M\&E/GVA) t & $\begin{array}{c}0.029 * * \\
(0.014)\end{array}$ & $\begin{array}{c}0.029 * * \\
(0.014)\end{array}$ & $\begin{array}{c}0.034 * * \\
(0.013)\end{array}$ & $\begin{array}{c}0.032 * * \\
(0.014)\end{array}$ & & $\begin{array}{c}0.016 * * \\
(0.007)\end{array}$ & $\begin{array}{c}0.021 * * \\
(0.011)\end{array}$ & $\begin{array}{c}0.019 * * \\
(0.009)\end{array}$ \\
\hline $\log$ (Investment M\&E/GVA) t-1 & & & & & $\begin{array}{c}0.028 * * \\
(0.012)\end{array}$ & & & \\
\hline $\log ($ Imports/GVA) t & & $\begin{array}{l}-0.017 \\
(0.022)\end{array}$ & $\begin{array}{c}-0.014 \\
(0.021)\end{array}$ & $\begin{array}{l}-0.024 \\
(0.033)\end{array}$ & & $\begin{array}{l}-0.006 \\
(0.079)\end{array}$ & $\begin{array}{l}0.039 \\
(0.116)\end{array}$ & $\begin{array}{l}-0.041 \\
(0.127)\end{array}$ \\
\hline $\log ($ Imports/GVA) t-1 & & & & & $\begin{array}{l}-0.010 \\
(0.020)\end{array}$ & & & \\
\hline $\log ($ Exports/GVA) t & & & $\begin{array}{l}-0.034 \\
(0.027)\end{array}$ & $\begin{array}{l}-0.027 \\
(0.031)\end{array}$ & & $\begin{array}{l}-0.028 \\
(0.040)\end{array}$ & $\begin{array}{l}0.057 \\
(0.088)\end{array}$ & $\begin{array}{l}0.050 \\
(0.080)\end{array}$ \\
\hline $\log ($ Exports/GVA) $t-1$ & & & & & $\begin{array}{l}-0.029 \\
(0.033)\end{array}$ & & & \\
\hline $\log$ (Skilled/Unskilled Workers) t & & & & $\begin{array}{l}0.038 \\
(0.077)\end{array}$ & & & & $\begin{array}{l}-0.063 \\
(0.075)\end{array}$ \\
\hline $\log$ (Male/Female Workers) $t$ & & & & $\begin{array}{l}0.006 \\
(0.022)\end{array}$ & & & & $\begin{array}{l}-0.038 \\
(0.024)\end{array}$ \\
\hline Year Fixed Effects & Yes & Yes & Yes & Yes & Yes & Yes & Yes & Yes \\
\hline Sector Fixed Effects & No & No & No & No & No & Yes & No & No \\
\hline First Differences & No & No & No & No & No & No & Yes & Yes \\
\hline Observations & 154 & 154 & 154 & 154 & 154 & 154 & 140 & 140 \\
\hline
\end{tabular}

Note 1: * Significant at $10 \%$ level. ** Significant at 5\% level. *** Significant at $1 \%$ level.

Note 2: Industry-specific skill premia in each year are expressed as deviations from the employment-weighted average skill premium for the manufacturing sector of the corresponding year (Krueger and Summer, 1988).

Note 3: Each sector-year observation is weighted by the inverse of the standard error of the sectorial skill premium (Krueger and Summer, 1988).

Note 3: Robust Huber-White standard errors in parenthesis (clustering by industry). 


\section{Table 4}

\section{Models of Skill Premia for High-School Graduates}

Dependent Variable: Logarithm of the real hourly wage of the main occupation

Estimation at the individual level (males and females aged 18 to 65, with positive wage earnings)

Manufacturing Sector, Argentina, 1991-2001

\begin{tabular}{llllll}
\hline Model & $(1)$ & $(2)$ & $(3)$ & $(4)$ & $(5)$ \\
\hline
\end{tabular}

\section{Capital Accumulation}

$\begin{array}{lccccc}\text { Without a high-school degree } & -0.015 * * * & -0.015^{* * *} & -0.015^{* * *} & -0.008^{* * *} & -0.006^{* * * *} \\ & (0.003) & (0.003) & (0.003) & (0.002) & (0.002) \\ \text { High-School Graduates } & -0.005 & -0.005 & -0.005 & 0.003 & 0.004 \\ & (0.003) & (0.003) & (0.003) & (0.003) & (0.003) \\ \text { College Graduates } & 0.018^{* * *} & 0.017^{* * *} & 0.017 * * * & 0.025^{* * *} & 0.023^{* * *} \\ & (0.005) & (0.006) & (0.006) & (0.005) & (0.005)\end{array}$

Import Penetration

$\begin{array}{lcccc}\text { Without a high-school degree } & 0.016 & 0.018 & -0.001 & -0.056^{* * *} \\ & (0.023) & (0.023) & (0.017) & (0.017) \\ \text { High-School Graduates } & 0.004 & 0.005 & -0.011 & -0.062^{* * *} \\ & (0.023) & (0.023) & (0.017) & (0.018) \\ \text { College Graduates } & 0.002 & 0.004 & -0.011 & -0.056^{* * *} \\ & (0.025) & (0.023) & (0.020) & (0.020)\end{array}$

Exports

$\begin{array}{lccc}\text { Without a high-school degree } & 0.007 & -0.008 & -0.019 \\ & (0.012) & (0.012) & (0.012) \\ \text { High-School Graduates } & -0.001 & -0.014 & -0.023^{*} \\ \text { College Graduates } & (0.013) & (0.013) & (0.013) \\ & -0.002 & -0.021 & -0.027 \\ & (0.021) & (0.021) & (0.021)\end{array}$

\begin{tabular}{lccccc} 
Demographic Controls & Yes & Yes & Yes & Yes & Yes \\
Year Indicators & Yes & Yes & Yes & Yes & Yes \\
Regional Indicators & Yes & Yes & Yes & Yes & Yes \\
Sector Indicators & Yes & Yes & Yes & Yes & Yes \\
\hline Observations & 34,091 & 34,091 & 34,091 & 34,091 & 32,238 \\
\hline
\end{tabular}

Note 1: * Significant at $10 \%$ level. ** Significant at 5\% level. *** Significant at $1 \%$ level. Note 2: The regression also includes demographic controls (education, age, and gender) interacted with yearly indicators, as well as year, industry, and regional fixed effects.

Note 2: Robust Huber-White standard errors in parenthesis (clustering by industry).

Note 3: Control variables in Column (4) are lagged one period, while control variables in Column (5) are lagged two periods. 